\title{
Immunohistochemical characterization of urethane-induced lung tumors in CB6F1-Tg rasH2 mice
}

\author{
Tomoya Sano $^{1 *}$, Takeshi Watanabe ${ }^{1}$, Yoshimasa Ishimura ${ }^{1}$, and Hisashi Anayama ${ }^{1}$ \\ ${ }^{1}$ Drug Safety Research Laboratories, Takeda Pharmaceutical Company Limited, 26-1 Muraoka-Higashi 2-Chome, Fujisawa, \\ Kanagawa 251-8555, Japan
}

\begin{abstract}
The purpose of this study was to define the histopathological characteristics of pulmonary neoplastic lesions, especially focusing on the origin of tumor cells, in urethane-treated $\mathrm{Tg}$ rasH2 mice. Bronchiolar-alveolar adenomas/adenocarcinomas were observed in the lungs from all of the urethane-treated animals. Immunohistochemically, these tumors showed an alveolar epithelial type II (AE2) cell phenotype demonstrating positive staining of surfactant protein C (SP-C). Cells expressing Clara cell 10 (CC10), a Clara cell marker, were also observed in a scattered manner in some tumors. Several SP-C and CC10 double-positive cells were observed in these tumors. Most of the urethane-induced pulmonary tumors were considered to have an AE2 cell phenotype, but the presence of SP-C and CC10 double positive cells in the tumors of Tg rasH2 mice suggests that some tumors arose from bronchioalveolar stem cells, which are known to express both SP-C and CC10. (DOI: 10.1293/tox.2016-0066; J Toxicol Pathol 2017; 30: 177-181)
\end{abstract}

Key words: urethane, lung tumor, $\mathrm{Tg} \operatorname{ras} \mathrm{H} 2$ mice

Urethane, a well known pulmonary carcinogen in mice, has been used as a positive control for carcinogenicity studies in $\mathrm{Tg}$ rasH2 mice ${ }^{1,2}$. Rodent pulmonary tumors are classically believed to arise from alveolar epithelial type II (AE2) cells or Clara cells, but are generally considered to arise from AE2 cells ${ }^{3}$. Recently, the cells expressing both surfactant protein C (SP-C) and Clara cell 10 (CC10) were identified in the bronchioalveolar duct junction as bronchioalveolar stem cells (BASCs), which have the potential to differentiate into AE2 and Clara cells, in Lox-K-ras mice, and BASCs were also considered to play an important role in pulmonary tumorigenesis ${ }^{4,5}$. However, there are no reports that define the cellular origin of urethane-induced lung tumors in $\mathrm{Tg}$ rasH2 mice, particularly the involvement of BASCs. Therefore, we evaluated the histopathological characteristics of urethane-induced lung neoplastic lesions in $\mathrm{Tg}$ rasH2 mice using pulmonary epithelial markers in the present study.

The experimental procedures were approved by the Institutional Animal Care and Use Committees of Shonan Research Center, Takeda Pharmaceutical Company Ltd. Six-week-old CB6F1 Tg rasH2 mice (15 mice/sex) obtained from CLEA Japan (Shizuoka, Japan) were housed in metal

Received: 9 November 2016, Accepted: 14 December 2016 Published online in J-STAGE: 5 January 2017

*Corresponding author: T Sano (e-mail: tomoya.sano@takeda.com) (C2017 The Japanese Society of Toxicologic Pathology

This is an open-access article distributed under the terms of the Creative Commons Attribution Non-Commercial No Derivatives (by-nc-nd) License. (CC-BY-NC-ND 4.0: https://creativecommons. org/licenses/by-nc-nd/4.0/). cages in an animal room at Takeda Pharmaceutical Company Ltd. (Kanagawa, Japan). The room was maintained at $20^{\circ} \mathrm{C}$ to $26^{\circ} \mathrm{C}$ with a relative humidity of $40 \%$ to $80 \%$ and a 12-hour light/dark cycle. All mice were fed a commercial diet (CE-2, CLEA Japan, Tokyo, Japan) and tap water ad libitum. Urethane was purchased from Tokyo Chemical Industry Co., Ltd., and dissolved in saline (Otsuka Pharmaceutical Factory, Inc.). After a 7-day acclimatization period, the 7-week-old mice received 3 intraperitoneal (i.p.) injections of urethane $(1000 \mathrm{mg} / \mathrm{kg} / \mathrm{day}, 10 \mathrm{~mL} / \mathrm{kg}$ in saline, every other day), which is a regimen known to cause lung and splenic tumors ${ }^{6}$. Two male and 2 female mice were found dead, and 4 moribund male mice were euthanized between 19 and 24 weeks of age. At 24 weeks of age, the remaining animals were euthanized by exsanguination via the $a b-$ dominal aorta under inhalation anesthesia with isoflurane. At necropsy, all mice including those found to be moribund and euthanized and found dead showed multiple white and/ or dark-red nodules in the lungs (Fig. 1), and hydrothrax was noted in some cases. Lungs were fixed by intratracheal instillation and immersion in $10 \%(\mathrm{v} / \mathrm{v})$ neutral buffered formalin, paraffin-embedded in toto with the ventral surface down, sectioned in the longitudinal-horizontal axis, and stained with hematoxylin and eosin (H\&E). Histopathological changes in the lung were diagnosed according to the International Harmonization of Nomenclature and Diagnostic Criteria (INHAND) for respiratory lesions in rats and mice $^{3}$. To identify phenotypes of the tumor cells, lung sections were stained immunohistochemically with anti-CC10 and anti-pro-surfactant protein $\mathrm{C}$ (anti-proSP-C) antibodies. Details of the staining conditions for each primary antibody are summarized in Table 1. Furthermore, double staining of 


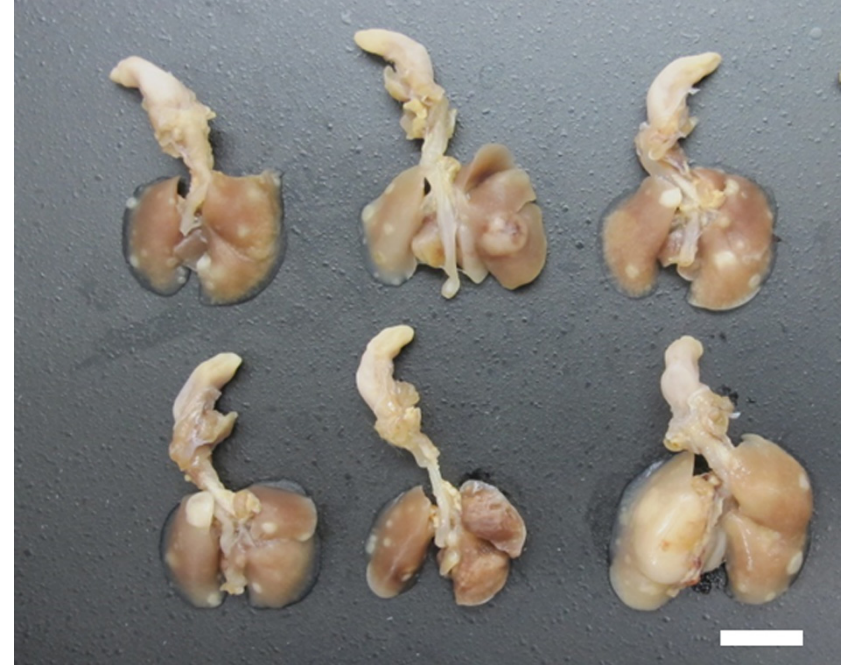

Fig. 1. Macroscopic features of the lung in urethane-treated $\mathrm{Tg}$ rasH2 mice. Multiple white nodules in the lung can be seen (bar: $10 \mathrm{~mm}$ ).

Table 1. Primary Antibodies and Reaction Conditions for Immunohistochemistry

\begin{tabular}{lccccc}
\hline Antigen & Clonality & $\begin{array}{c}\text { Manufac- } \\
\text { turer }\end{array}$ & $\begin{array}{c}\text { Antigen } \\
\text { retrieval }\end{array}$ & Dilution & $\begin{array}{c}\text { Detection system } \\
\text { and secondary } \\
\text { antibody }\end{array}$ \\
\hline $\begin{array}{l}\text { Human } \\
\text { proSP-C }\end{array}$ & Poly & $\begin{array}{c}\text { AbCam } \\
\text { (ab90716) }\end{array}$ & $\begin{array}{c}\text { AC/TR } \\
\text { solution }\end{array}$ & $1: 1,000$ & ENVISION+/ \\
$\begin{array}{lcccc}\text { Mouse } \\
\text { CC10 }\end{array}$ & Poly & Santa & AC/TR & $1: 5,000$ & HRP, anti-rabbit \\
& & $\begin{array}{c}\text { Elite ABC kit, } \\
\text { Cruz } \\
\text { (SC-9772) }\end{array}$ & solution & & $\begin{array}{c}\text { Biotinylated anti- } \\
\text { goat lgG }\end{array}$ \\
\hline
\end{tabular}

$\mathrm{AC}$, Autoclave $\left(121^{\circ} \mathrm{C}, 20 \mathrm{~min}\right)$; HRP, horseradish peroxidase; $\mathrm{PO}$ peroxidase; TR solution, Target Retrieval solution (DAKO), Poly, polyclonal antibody.

Table 2. Incidences of Proliferative Lesions in the Lung

\begin{tabular}{lcc}
\hline Sex & Male & Female \\
\hline Number of animals examined & 15 & 15 \\
Hyperplasia & $13(87 \%)$ & $11(73 \%)$ \\
Adenoma & $15(100 \%)$ & $15(100 \%)$ \\
Adenocarcinoma & $9(60 \%)$ & $10(67 \%)$ \\
Hemangiosarcoma & $4(27 \%)$ & $3(20 \%)$ \\
\hline
\end{tabular}
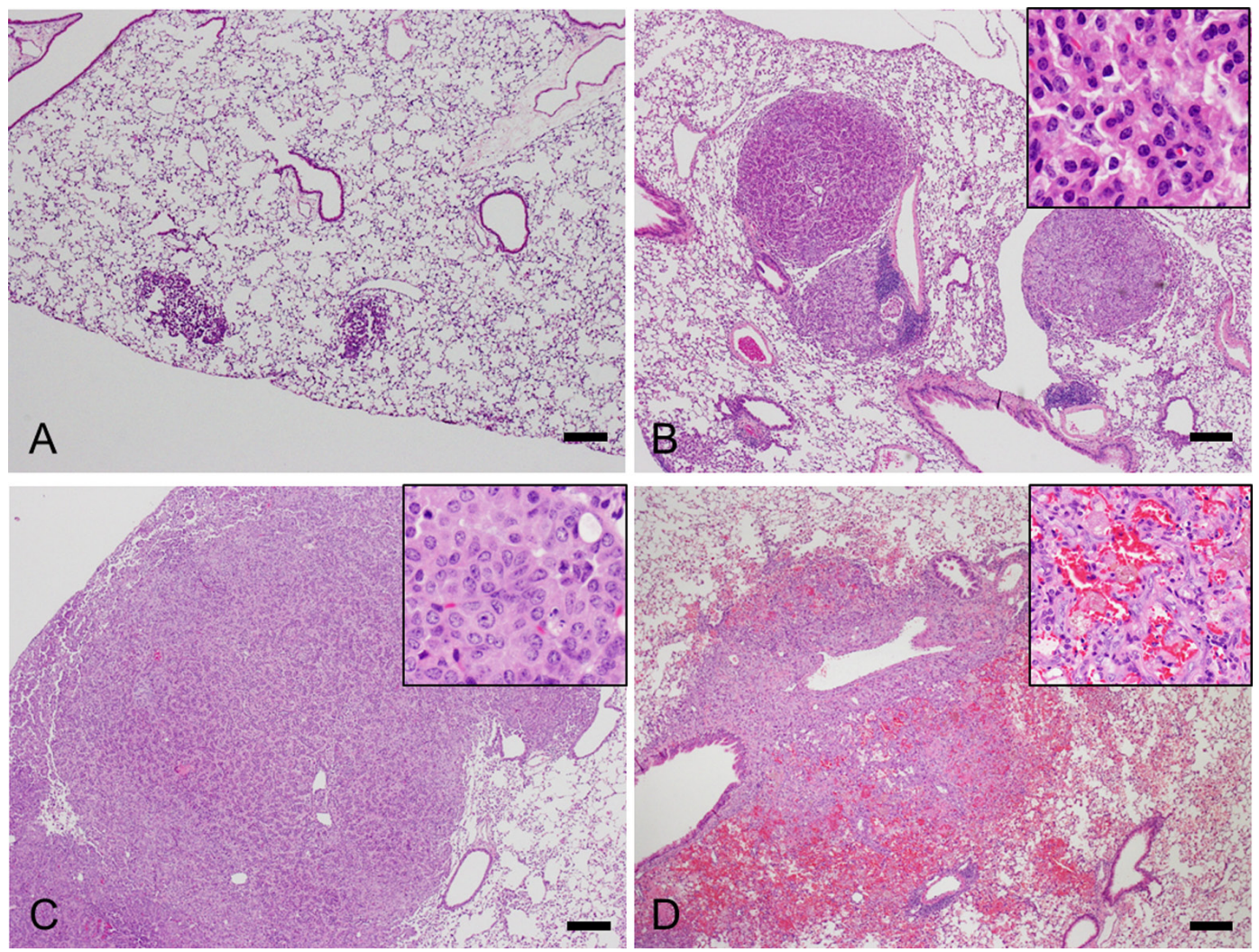

Fig. 2. H\&E staining showing proliferative lesions in a urethane-treated $\mathrm{Tg}$ rasH2 mouse. A: Bronchiolar-alveolar hyperplasia (bar, 200 $\mu \mathrm{m})$. B: Bronchiolar-alveolar adenoma (bar, $200 \mu \mathrm{m}$; inset, higher magnification image). C: Bronchiolar-alveolar adenocarcinoma (bar, $200 \mu \mathrm{m}$; inset, higher magnification image). D: Hemangiosarcoma in the lung (bar, $200 \mu \mathrm{m}$; inset, higher magnification image). 

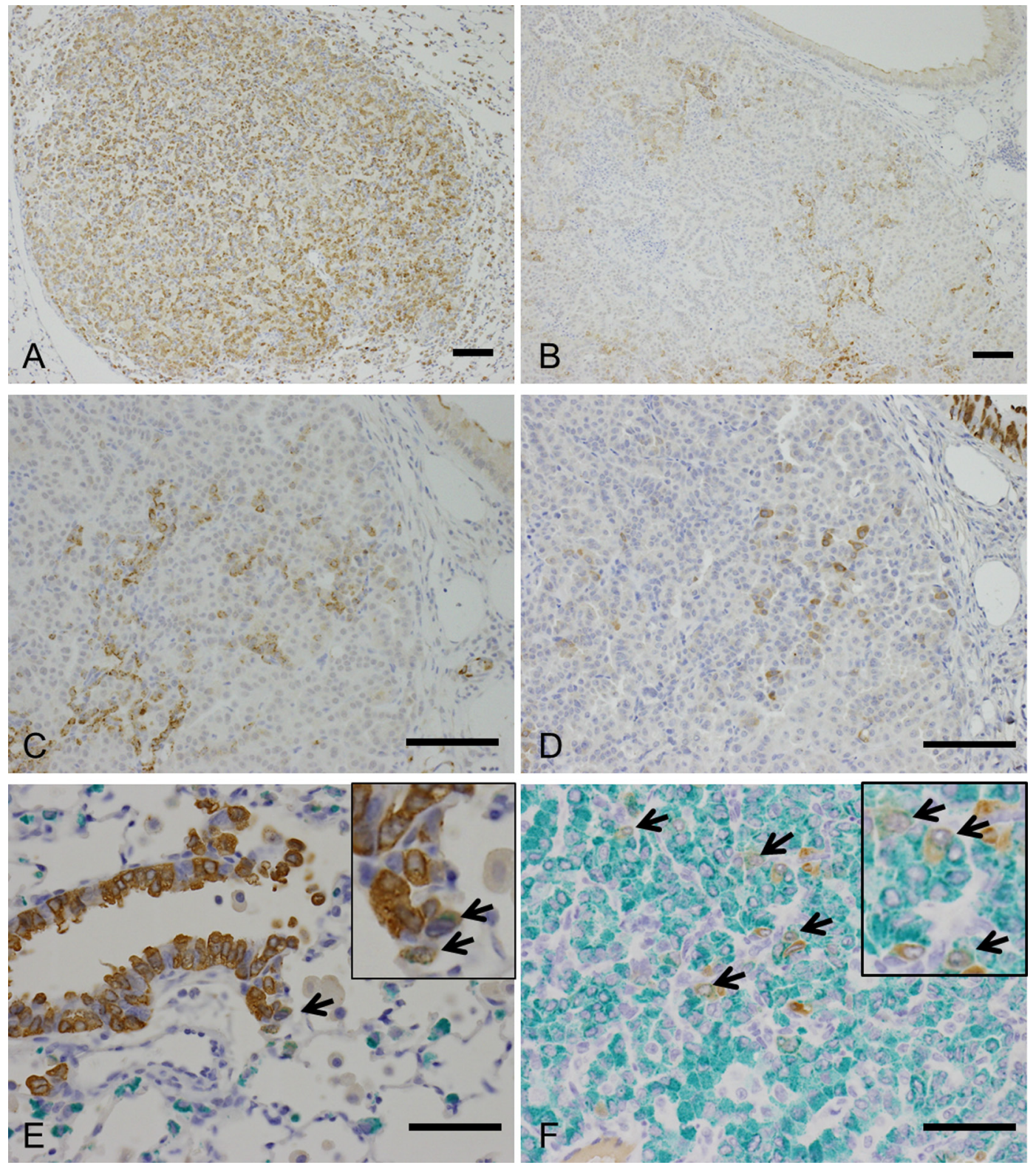

Fig. 3. Immunohistochemistry for proliferative lesions in a urethane-treated $\mathrm{Tg}$ ras $\mathrm{H} 2$ mouse. A: Bronchiolar-alveolar adenomas are diffusely positive for SP-C, an AE2 cell marker (bar: $100 \mu \mathrm{m}$ ). B: Bronchiolar-alveolar carcinomas contain scattered cells positive for SP-C (bar: $100 \mu \mathrm{m}$ ). C: Higher magnification of Fig. 3B (bar: $100 \mu \mathrm{m}$ ). D: Section adjacent to that in figure 3C. Bronchiolar-alveolar carcinomas contain scattered cells positive for CC10, a Clara cell marker (bar: $100 \mu \mathrm{m}$ ). E: SP-C and CC10 double-positive cells (arrow) in the nonproliferative area (bronchioalveolar duct junction) of the lung in urethane-treated $\mathrm{Tg}$ ras 2 mice (bar, $100 \mu \mathrm{m}$; inset, higher magnification image). F: SP-C and CC10 double-positive cells (arrows) in the tumor of urethane-treated Tg rasH2 mice (bar, $100 \mu \mathrm{m}$; green, SP-C; brown, CC10; inset, higher magnification image). The staining intensity of SP-C and CC10 in the double-positive cells in the normal bronchiole and tumors is weaker than that in the normal AE2 or Clara cells.

SP-C (green: HistoGreen) and CC10 (brown: 3',3'-diaminobenzidine- $4 \mathrm{HCl}[\mathrm{DAB}])$ were conducted for the tumors that contained CC10-positive tumor cells. The grade of SP-C or CC10 immunohistochemistry was judged as follows: -, tumors negatively stained; $+/-$, tumors partially stained (SPC) or a small number of tumor cells stained (CC10); and + , tumor diffusely stained. The incidence rates (\%) of tumors negatively or positively $(+/-$ or +$)$ stained with SP-C or $\mathrm{CC} 10$ and tumors with SP-C/CC10 double-positive cells were calculated, respectively.
Microscopically, multiple bronchiolar-alveolar hyperplasia, adenomas, and/or adenocarcinomas were observed in the lung in all the urethane-treated mice (Figs. 2A-C, Table 2). In addition, some urethane-treated animals showed hemangiosarcoma in the lung (Fig. 2D, Table 2). Immunohistochemically, bronchiolar-alveolar hyperplasia (data not shown), adenoma, and adenocarcinoma showed SP-C expression, suggesting that the tumors were derived from AE2 cells in urethane-treated mice (Fig. 3A, Table 3). Most cells in the hyperplastic lesions and neoplastic lesions were 
Table 3. Results of Immunohistochemistry: Incidences and Staining Grades of Tumors

\begin{tabular}{|c|c|c|c|c|c|c|c|c|c|}
\hline \multirow{3}{*}{ Sex } & \multirow{3}{*}{ Tumor type } & \multirow{3}{*}{$\begin{array}{l}\text { Total No. } \\
\text { of tumors }\end{array}$} & \multicolumn{7}{|c|}{ Number of positively stained tumors } \\
\hline & & & \multicolumn{3}{|c|}{ SP-C } & \multicolumn{3}{|c|}{$\mathrm{CC} 10$} & \multirow{2}{*}{$\frac{\text { SP-C/CC10 }}{\text { Positive }^{\#}}$} \\
\hline & & & - & $+/-$ & + & - & $+/-$ & + & \\
\hline \multirow[t]{4}{*}{ M } & Adenoma & 136 & 3 & 8 & 125 & 126 & 10 & 0 & 5 \\
\hline & & & $2.2 \% *$ & $5.9 \%$ & $91.9 \%$ & $92.6 \% *$ & $7.4 \%$ & $0.0 \%$ & $3.7 \%$ \\
\hline & Adenocarcinoma & 15 & 0 & 12 & 3 & 9 & 6 & 0 & 2 \\
\hline & & & $0.0 \%$ & $80.0 \%$ & $20.0 \%$ & $60.0 \%$ & $40.0 \%$ & $0.0 \%$ & $13.3 \%$ \\
\hline \multirow[t]{4}{*}{$\mathrm{F}$} & Adenoma & 139 & 0 & 9 & 130 & 137 & 2 & 0 & 1 \\
\hline & & & $0.0 \%$ & $6.5 \%$ & $93.5 \%$ & $98.6 \%$ & $1.4 \%$ & $0.0 \%$ & $0.7 \%$ \\
\hline & Adenocarcinoma & 20 & 0 & 16 & 4 & 20 & 0 & 0 & 0 \\
\hline & & & $0.0 \%$ & $80.0 \%$ & $20.0 \%$ & $100.0 \%$ & $0.0 \%$ & $0.0 \%$ & $0.0 \%$ \\
\hline
\end{tabular}

M, male; F, female; -, tumors negatively stained; +--, tumors partially stained for SP-C, with a small number of tumor cells stained for $\mathrm{CC} 10 ;+$, tumor diffusely stained. , tumor with a small number of SP-C/CC10 double-positive cells. *, The incidence rate (\%) was calculated as follows: (the number of tumors negatively/positively $[+/-$ or +$]$ stained with SP-C or CC10 or the number of tumors with SP-C/ CC10 double-positive cells / the total number of tumors) $\times 100$.

positive for SP-C; however, some tumor cells were negative for SP-C (Fig. 3B, Table 3). Interestingly, a small number of CC10-positive cells were also observed in a scattered manner in some adenomas and adenocarcinomas, which contained SP-C-expressing tumor cells (Figs. 3C and 3D, Table 3). Double staining of SP-C and CC10 showed that most of the tumor cells expressed SP-C or CC10 alone; however, a small number of double-positive cells were observed in these tumors (Fig. 3F). In the non-lesional area of the sections, small number of double positive cells in a few animals were also noted near the bronchoalveolar duct junctions of the terminal bronchiole (Fig. 3E). The staining intensity of SP-C and CC10 in the SP-C and CC10 double-positive cells in the normal bronchiole and tumors was weaker than that in the normal AE2 or Clara cells. The presence and immunohistochemical staining pattern of the SP-C and CC10 double-positive cells in the tumors resembled those of the BASCs found near the bronchoalveolar duct junctions as well as those reported in previous literatures ${ }^{4,5}$, suggesting that some of the urethane-induced lung tumors in the $\mathrm{Tg}$ rasH2 mice arose from BASCs.

It has been reported that a small number of BASCs were found in lung tumors of Lox-K-ras G12D mice. ${ }^{7}$. On the other hand, Mason et al. reported that the expression of SP-C but not CC10 was observed in urethane-induced bronchiolar-alveolar adenomas of $\mathrm{A} / \mathrm{J}$ mice, which are known to have a high incidence of spontaneous lung tumors ${ }^{8,9}$. Bioactivated urethane causes mutations in the K-ras and/or p53 gene in $\mathrm{A} / \mathrm{J}$ mice $^{10}$. In Tg rasH2 mice, point mutation of the human c-Ha-ras transgene was frequently observed in urethane-induced lung tumor cells ${ }^{11}$. Therefore, the occurrence of BASCs with pulmonary tumors in $\mathrm{Tg}$ ras $\mathrm{H} 2$ mice might be related to the differences in mutated genes and/ or the genetic backgrounds of the mouse strains. However, further studies, such as the investigation for the involvement of BASCs in the initial phase of pulmonary tumorigenesis, will be needed to clarify the significance of BASCs in urethane-induced lung tumor of $\mathrm{Tg}$ rasH2 mice.

In the present study, we demonstrated that although most of the pulmonary tumors were positive for SP-C only, some tumors contained SP-C and CC10 double-positive cells, suggesting the association of BASCs with urethaneinduced pulmonary tumorigenesis in $\mathrm{Tg}$ rasH2 mice. Understanding the characteristics of induced pulmonary tumors is important. This study will provide useful information regarding lung carcinogenicity evaluation in $\mathrm{Tg}$ rasH2 mice, especially for genotoxic compounds like urethane.

Acknowledgment: The authors would like to thank Ms. Naoko Awasaki for her excellent technical support during this work.

Disclosure of Potential Conflict of Interest: The authors declare that there are no conflict of interest associated with this paper.

\section{References}

1. Long GG, Morton D, Peters T, Short B, and Skydsgaard M. Alternative mouse models for carcinogenicity assessment: industry use and issues with pathology interpretation. Toxicol Pathol. 38: 43-50. 2010. [Medline] [CrossRef]

2. Paranjpe MG, Elbekaei RH, Shah SA, Hickman M, Wenk ML, and Zahalka EA. Historical control data of spontaneous tumors in transgenic CByB6F1-Tg(HRAS)2Jic (Tg. rasH2) mice. Int J Toxicol. 32: 48-57. 2013. [Medline] [CrossRef]

3. Renne R, Brix A, Harkema J, Herbert R, Kittel B, Lewis D, March T, Nagano K, Pino M, Rittinghausen S, Rosenbruch $\mathrm{M}$, Tellier P, and Wohrmann T. Proliferative and nonproliferative lesions of the rat and mouse respiratory tract. Toxicol Pathol. 37(7 Suppl): 5S-73S. 2009. [Medline] [CrossRef]

4. Kim CF, Jackson EL, Woolfenden AE, Lawrence S, Babar I, Vogel S, Crowley D, Bronson RT, and Jacks T. Identification of bronchioalveolar stem cells in normal lung and lung cancer. Cell. 121: 823-835. 2005. [Medline] [CrossRef]

5. Sutherland KD, and Berns A. Cell of origin of lung cancer. Mol Oncol. 4: 397-403. 2010. [Medline] [CrossRef] 
6. Shah SA, Paranjpe MG, Atkins PI, and Zahalka EA. Reduction in the number of animals and the evaluation period for the positive control group in Tg.rasH2 short-term carcinogenicity studies. Int J Toxicol. 31: 423-429. 2012. [Medline] [CrossRef]

7. Jackson EL, Willis N, Mercer K, Bronson RT, Crowley D, Montoya R, Jacks T, and Tuveson DA. Analysis of lung tumor initiation and progression using conditional expression of oncogenic K-ras. Genes Dev. 15: 3243-3248. 2001. [Medline] [CrossRef]

8. Malkinson AM. Genetic studies on lung tumor susceptibility and histogenesis in mice. Environ Health Perspect. 93: 149-159. 1991. [Medline] [CrossRef]

9. Mason RJ, Kalina M, Nielsen LD, Malkinson AM, and
Shannon JM. Surfactant protein C expression in urethaneinduced murine pulmonary tumors. Am J Pathol. 156: 175182. 2000. [Medline] [CrossRef]

10. Horio Y, Chen A, Rice P, Roth JA, Malkinson AM, and Schrump DS. Ki-ras and p53 mutations are early and late events, respectively, in urethane-induced pulmonary carcinogenesis in A/J mice. Mol Carcinog. 17: 217-223. 1996. [Medline] [CrossRef]

11. Tomisawa M, Suemizu H, Ohnishi Y, Maruyama C, Urano K, Usui T, Yasuhara K, Tamaoki N, and Mitsumori K. Mutation analysis of vinyl carbamate or urethane induced lung tumors in rasH2 transgenic mice. Toxicol Lett. 142: 111-117. 2003. [Medline] [CrossRef] 